\title{
Forest as a Resource and Component of a Watershed, its Degradation and Conservation: A Case of Somb Drainage Basin
}

\author{
Vipin Kumar \\ Assistant Professor, Deptt. of Geography, Banasthali University, Banasthali, (Rajasthan)- 304022
}

\begin{abstract}
This paper explains about the present status of forest conditions in the study area, which is one of the most striking resources of present watershed. The methodology used to the study of forest is satellite image interpretation, intensive field investigations and secondary data collection from forest department. The forest in watershed area have mainly four types viz.- Siwaliks Chir-pine, Siwaliks Sal, Northern Dry Mixed Deciduous, and Dry Bamboo Brake. The present watershed occupies $167 \mathrm{~km}^{2}$ (2004-2005) forest area. It is almost 32.62 percent of the total area of watershed, which is very high than the national level (19 percent) and approximately equal to the standard level of 33 percent area set under national forest policy, 1952. More then 80 percent of the hills and foothills are covered by forests in present watershed, which is much higher than the recommended figure of 60 percent in hills, as prescribed by National Forest Policy. However, it is a matter of concern that the quality, in some areas, is not good. Presently, increasing mismanagement as well as stealthily cutting of forest trees is also serious problem in the watershed. So, there is a need to maintain the quality and quantity of trees in the watershed
\end{abstract}

\section{Introduction- Forest as a resource}

Forests are ecologically as well as economically important for modern civilization. Forests, 'all lands bearing a vegetational association dominated by trees of any size, exploited or not, capable of producing wood or other products, exerting an influence on climate or on the water regime or providing shelter for livestock and wildlife", are the vulnerable renewable resources of the 'biodiversity' as the plants basically support the survival of each and every members of the biome. Forest help in balancing $\mathrm{O}^{2}$ and $\mathrm{CO}^{2}$ level in the atmosphere, regulate earth's temperature regime and hydrological cycle. They increase local precipitation and water holding capacity of soil, thus preventing drought situation. Vegetation cover provided by forest, impeded the velocity of runoff on soil surface checks, soil erosion, silting and landslides, thus reducing the drought or flood. The litter derived from fallen leaves maintains fertility of soil by returning the nutrients. The forest resources are large in volume and diverse in character. On the other hand, the excess population pressure intensifies the demand of forest and forest products side by side. But unfortunately, these natural resources have been overlooked by the human kind, regarding the aspect of degrading trends of forest resources all over the world (Reddy, 2004 and Goswami, 2005).

The Word 'FOREST' can explain its value for life i.e.

$\mathrm{F}=$ Food, $\mathrm{O}=$ Oxygen $\left(\mathrm{O}^{2}\right)$, R=Rainfall, E=Ecological Balance, $\mathrm{S}=$ Soil, $\mathrm{T}=$ Tree

\section{Watershed and Forest}

Watershed (drainage basin, catchment), basically, a geographically area that drains to a common point, which make it an ideal planning unit for conservation of all the vital resources of nature i.e. Water, Forest, and Soil. A watershed is most environmentally logical way to divide earth's land into regions. In fact the entire earth surface comprises part of a watershed. Like the stream systems that they contain, watersheds are hierarchical and are conveniently subdivided into smaller sub-watersheds for local studies and management. At the same time, higher order watersheds of a large river system are subject to broad regional analysis.

Forested watersheds act as giant sponges, slowing down runoff, absorbing, and holding water that recharges spring, streams, and groundwater. Thus, they regulate the flow of water from mountain highlands to croplands and urban areas, they act as shields and reduce the amount of sediment washing into streams, lakes, and reservoirs by restricting soil erosion as the forest enrich soil-binding property (Anjaneyulu, A., 2004).

The types and qualities of vegetative cover in a watershed land influence runoff, infiltration rates, erosion and sediment production and the evapotransipration. A dense cover of vegetation in watershed is the most powerful weapon for reducing erosion. Vegetative conditions are related to hydrological conditions.

\section{Vegetative Conditions}

Heavily grazed or regularly burnt.

Small trees and brush are destroyed

Hydrologic Conditions

Grazed but not burnt, but these woods are not protected 
Good

Forests occupy the most land in India after agriculture, and are an important natural resource for the country and its people. The present study of the watershed has a good tree cover. There are twenty-five reserved forests (RF) and fourteen protected forests (PF) in the watershed area. The hilly area of watershed have almost reserved forest and covered with many tree species.

\section{The Study Area}

The Somb nadi is a tributary of Yamuna river, arise from the outer slope of the lower part of Shiwaliks range in the District Sirmaur (Himachal Pradesh, India) and takes a southerly course, which drains in the plain land of District Yamunanagar (Haryana, India). The Pathrala (also known as Palasi Khadi) and Boli nadi are two major tributaries of Somb nadi. Somb nadi combined with Pathrala and Boli nadi discharge its water into Yamuna River from western side near Meharmajara village of District Yamunanagar after about a course of 40 $\mathrm{kms}$. from its origin. The extension of Somb drainage basin lies between $77^{0} 18^{\prime} \mathrm{E}$ to $77^{0} 34^{\prime} \mathrm{E}$ longitude and $30^{0} 9^{\prime} \mathrm{N}$ to $30^{0} 29^{\prime} \mathrm{N}$ latitude. The total calculated area of Somb drainage basin is $492 \mathrm{kms}{ }^{2}$. Map- 1 shows the location of Somb drainage basin. Satellite imagery has been also prepared of Somb drainage basin (Image-1).

\section{Forest cover in Somb Drainage Basin}

The present watershed occupies $167.33 \mathrm{~km}^{2}$ (2004-2005) forest area. It is almost 32.72 percent of the total area of watershed, which is very high than the national level (19 percent) and approximately equal to the standard level of 33 percent area set under national forest policy, 1952. More then 80 percent of the hills and foothills are covered by forests in present watershed, which is much higher than the recommended figure of 60 percent in hills, as prescribed by National Forest Policy.

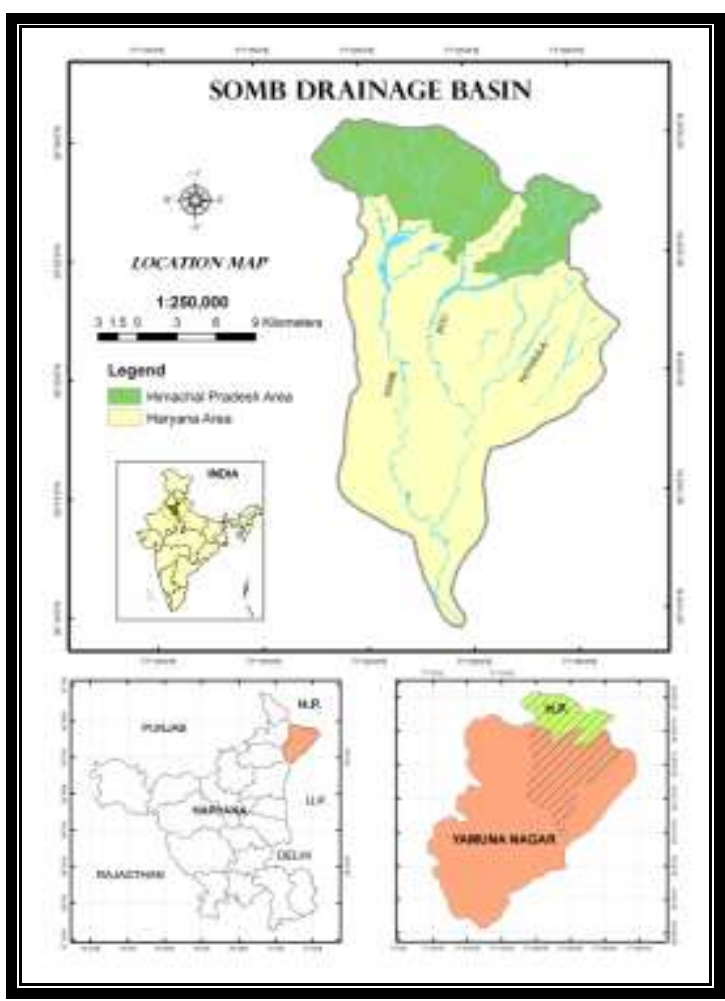

Map-1

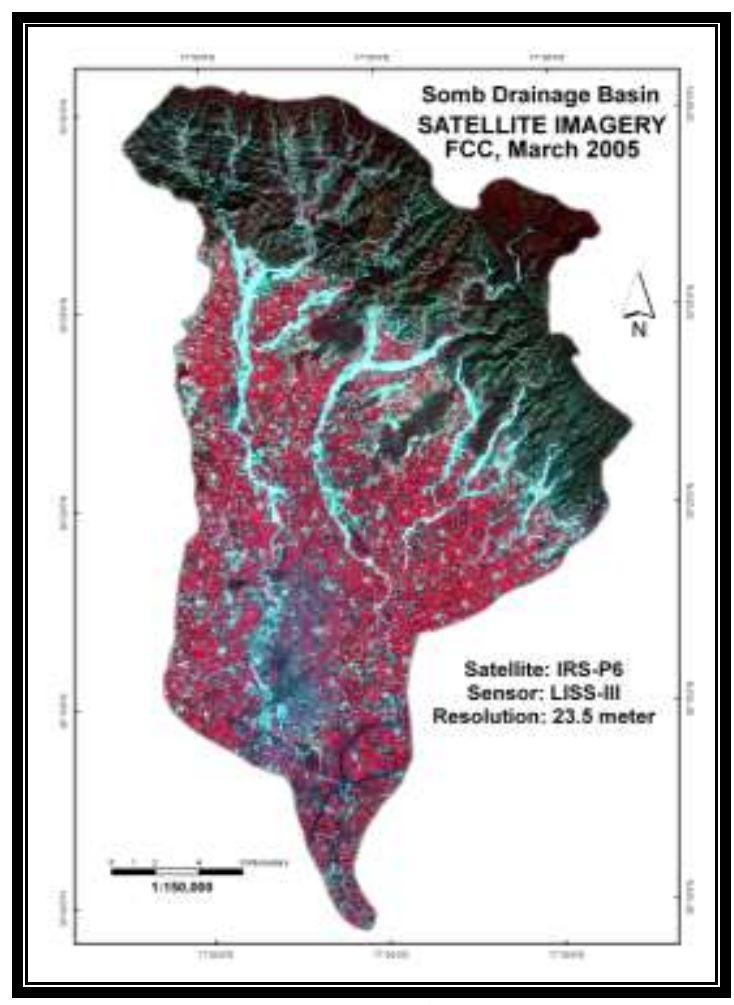

Image-1

The forest can be classified in two categories-

a) On the basis of vegetation curve

b) On the basis of Administration

\section{(a) On the Basis of Vegetation Curve}

On the basis of vegetation curve, Forests are further classified into three groups. Dense forest or closed forest, Open forest, and Crop area under forest. This has been studied through image interpretation of present watershed (Table-1, Map-2 \& Fig.-1). 


\section{Dense/Closed Forest}

The forested areas having more then 40 percent tree density are classified as dense forest (Anjaneyulu, Y. 2004). It is estimated that more then 96 percent $\left(161 \mathrm{~km}^{2}\right)$ of the total forest area is under dense vegetation curve, which constitutes 32.72 percent area of watershed.

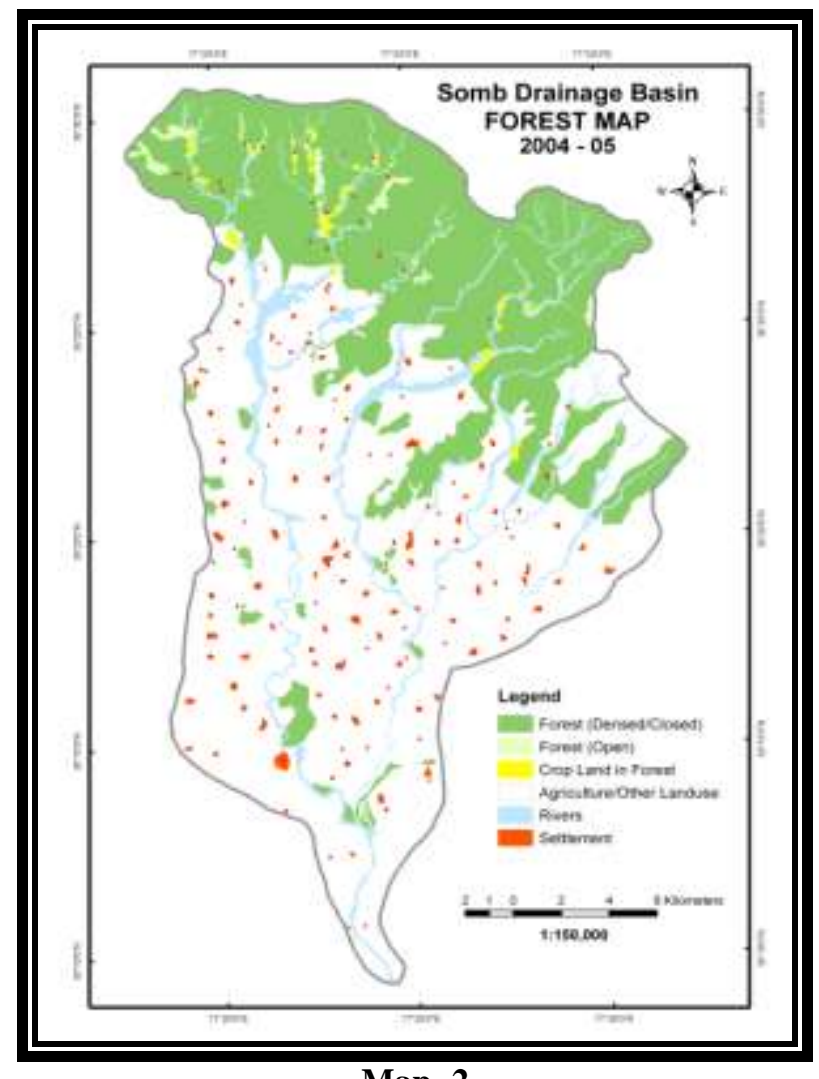

Map- 2

\section{Open forest}

The area having crown density between 10 to 40 percent are included into this group (Anjaneyulu, Y. 2004). It occupies just 3.2 sq. km (two per cent of forest area), which is 0.65 per cent of total geographical area of the watershed.

Table- 1

Somb Drainage Basin

Forest Cover (on the basis of vegetation cover)

\begin{tabular}{|l|l|l|l|}
\hline Forest & $\begin{array}{l}\text { Area } \\
\left(\mathbf{K m}^{\mathbf{2}}\right)\end{array}$ & $\begin{array}{l}\text { Percentage } \\
\text { of Forest } \\
\text { area }\end{array}$ & $\begin{array}{l}\text { Percentage } \\
\text { of } \\
\text { watershed } \\
\text { area }\end{array}$ \\
\hline $\begin{array}{l}\text { Dense/Closed } \\
\text { Forest }\end{array}$ & 161.02 & 96.22 & 32.72 \\
\hline Open Forest & 3.20 & 1.91 & 0.65 \\
\hline $\begin{array}{l}\text { Crop Land In } \\
\text { Forest }\end{array}$ & 3.11 & 1.85 & 0.63 \\
\hline Total & 167.33 & $99.9(100)$ & 34.00 \\
\hline
\end{tabular}

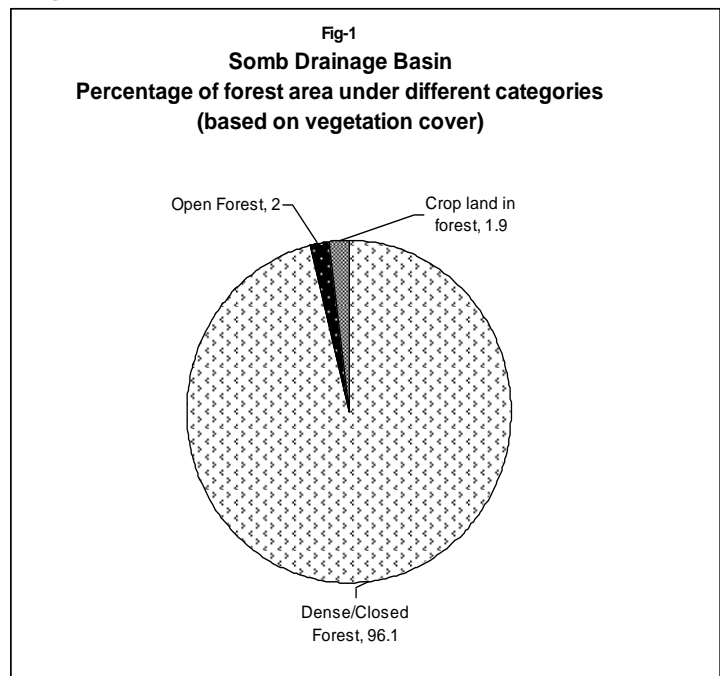

Source- Based on analysis of satellite image, March, 2005 


\section{Cropland under forest}

In forest area of watershed, some areas have been used for agriculture purposes, which is just $3.1 \mathrm{~km}^{2}$ of the total forestland.

\section{(b) On the Basis of Administration}

On the basis of administration, Forest department has divided the forests into three groups i.e. Reserved Forest, Protected Forest, and Unclassified forest. According to Forest department of Sirmaur, Himachal Pradesh and Yamunanagar, Haryana, the watershed has 29 Reserved Forest [17 Sirmaur (Himachal Pradesh) and 12 Yamunanagar (Haryana)], 16 Protected forest [(all in Yamunanagar (Haryana)] and one is unclassified forest situated in Yamunanagar, Haryana (Table- 2, Fig.-2 \& 3).

\section{Types of forest}

The forests of this region are of great importance for its economy as well as for maintaining the ecological balance of soil, water, flora, and fauna. The transitional location of the watershed between the outer Himalayas and the Yamuna upland plain has enriched it with a topographical variety.

Table- 2

Somb Drainage Basin

Forest Cover (on the basis of administration)

\begin{tabular}{|l|l|l|l|l|}
\hline Category & $\begin{array}{l}\text { Number of } \\
\text { Forests }\end{array}$ & $\begin{array}{l}\text { Area } \\
\left.\mathbf{k m}^{2}\right)\end{array}$ & $\begin{array}{l}\text { Percentage } \\
\text { of total } \\
\text { forest area }\end{array}$ & $\begin{array}{l}\text { Percentage } \\
\text { of total } \\
\text { watershed } \\
\text { area }\end{array}$ \\
\hline $\begin{array}{l}\text { Reserved } \\
\text { Forest }\end{array}$ & 29 & 105.58 & 65.78 & 21.45 \\
\hline $\begin{array}{l}\text { Protected } \\
\text { Forest }\end{array}$ & 16 & 54.71 & 34.15 & 11.12 \\
\hline $\begin{array}{l}\text { Unclassified } \\
\text { Forest }\end{array}$ & 1 & 0.20 & 0.12 & 0.04 \\
\hline Total & $\mathbf{4 6}$ & $\mathbf{1 6 0 . 5}$ & $\mathbf{1 0 0 . 0 0}$ & $\mathbf{3 2 . 6 1}$ \\
\hline
\end{tabular}

Source- DFO, Forest Department, Sirmaur (Himachal Pradesh) \& DFO, Forest Department, Yamunanagar, (Haryana)
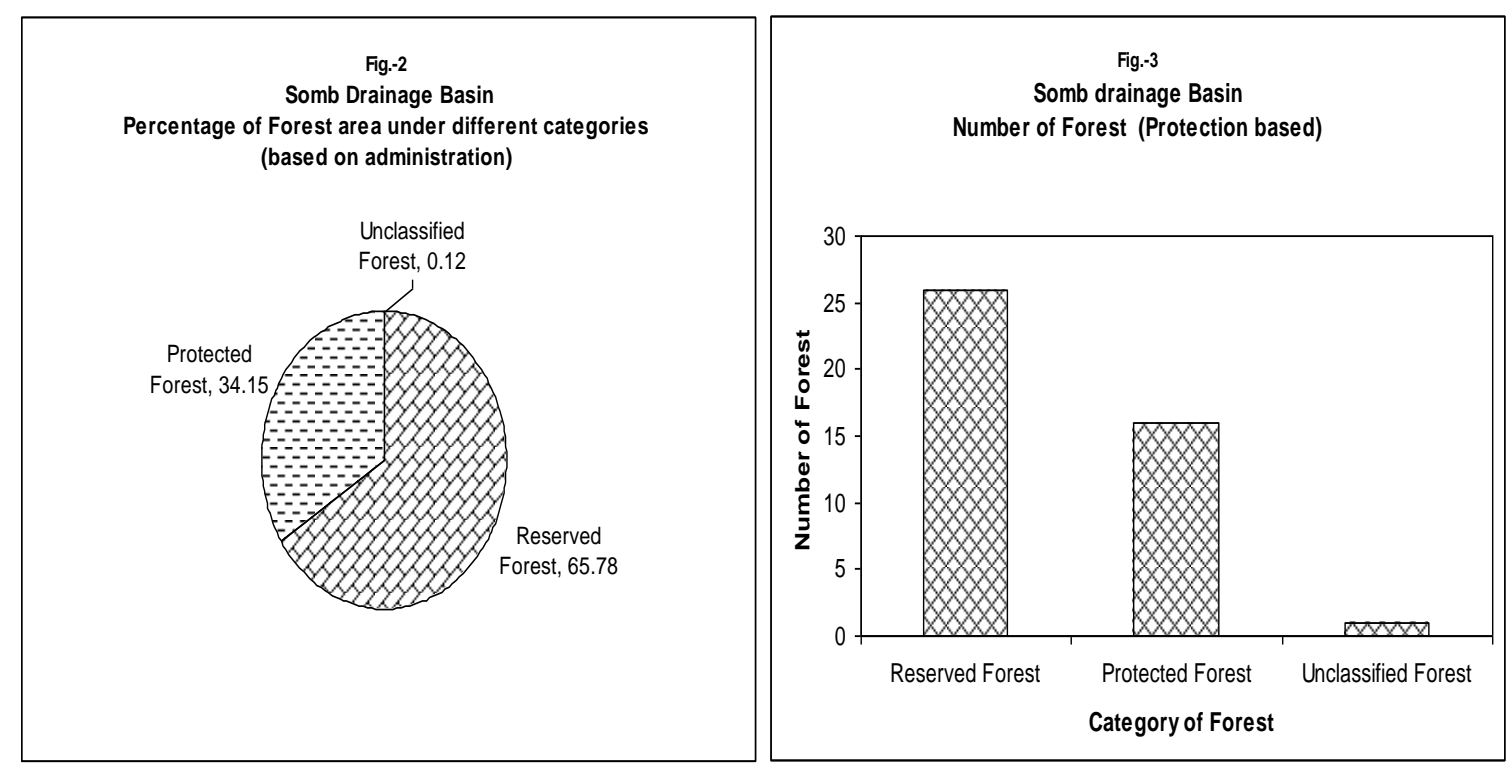

\section{The Scrubland}

Scrubland is an area, having ten percent tree density with more than fifty percent scrubs. These areas are found in patches and vary in size with irregular and discontinuous shape. Land under scrub occupies an area of about $34.5 \mathrm{~km}^{2}$, which is more than seven per cent of watershed area. Remaining area of wasteland i.e. area under scrub-less, is just one square kilometre. This is the area of rocks and stone waste or kankar, which are deposited by streams on their banks during rainy or flood season (Map-3). 


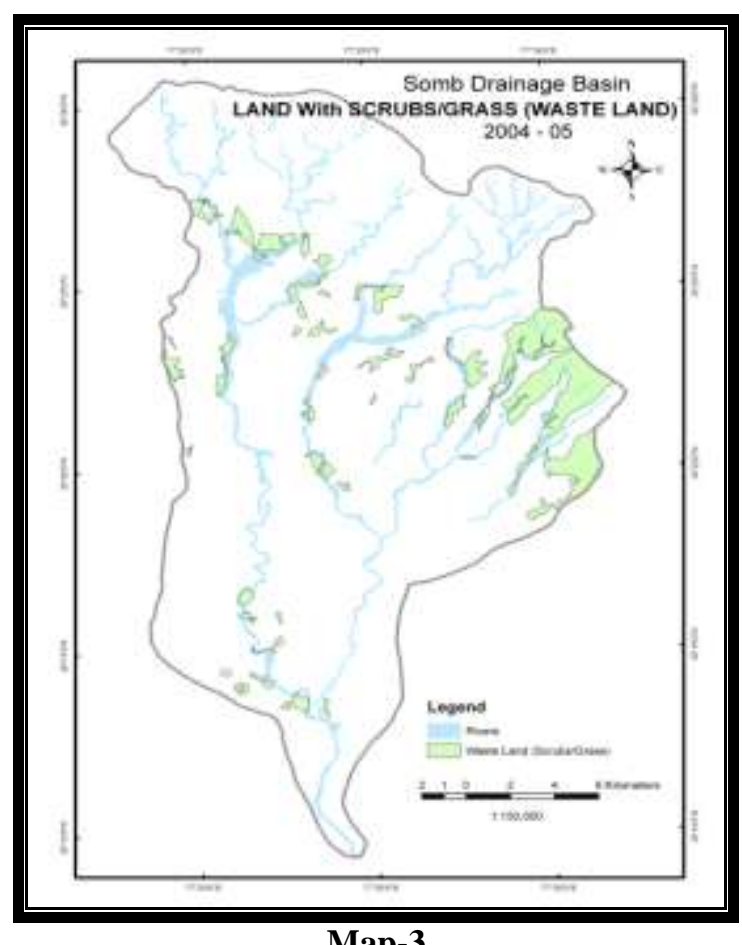

Medicinal plants are in great demand for the indigenous system of medicines mainly in Ayurveda. $C h$. Devi Lal Nature Herbal Park is established by the government of Haryana in Chhauharpur, at Chuharpur Reserved Forest near Khizrabad on Bhud Kalan road in Yamunanagar district. It is about $35 \mathrm{~km}$ away from Yamunanagar, $130 \mathrm{~km}$ from Chandigarh and $255 \mathrm{~km}$ from Delhi. Chuharpur Reserved Forest has an area of 184 Acre, with medium tree density of Khair (Acacia catechu), Teak (Tectona grandis), Simbal, Shisham (Dalbergia sissoo) etc. The park was opened on 6 November 2001. More than 300 species of medicinal trees, herbs, shrubs, climbers ferns and aquatic plants have been planted. Some of the important plants grown in the park are Ashwagandha, Sarpagandha, Safed Musali (Chlorophytum borivilianum L), Brahmi, Vach, Chitrak, Shatavari, Isabagol, Tulsi (Ocimum sanctum), Pippali, Makoy, Bhumi amalki, Bahera, Gwarpatha, Harad, Amla (Phyllanthus emblica), Rudraksh, Bael, Kalihari, Patharchur, Lemon grass, Liquorice, Jatropha, Palmarosa and Haldi (Turmeric).

The location of some major reserved forests (RF) in the present watershed are shown in Map- 4.

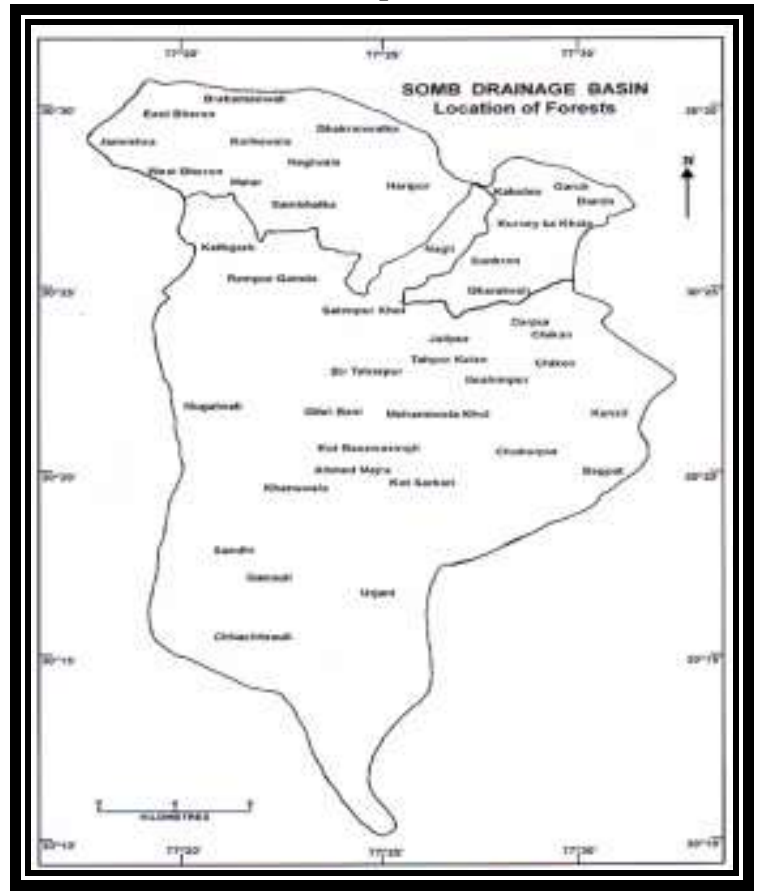

Map- 4 


\section{Utilization of Forest Resources in Somb Drainage Basin}

The main requirements of the people in watershed area, which are gained from the forest, are the following:

$\checkmark$ Building timber and small timber for agricultural implements,

$\checkmark \quad$ Fire wood

$\checkmark \quad$ Leaves of trees and grass for fodder

$\checkmark \quad$ Grazing of animals

Near watershed area, Yamunanagar-Jagadhri (Haryana), Nahan (Sirmaur, Himachal Pradesh), Saharanpur (Uttarpradesh) and Dhera Dun (Uttrakhand) are main market centers, where the demand of forests resources- mainly timber, is very high. Yamunanagar-Jagadhri is one of the biggest markets in India. It is well connected by rail, road, or both networks with other important market centers. The forest-based industries at Yamunanagar are paper mill, sawmills, hard board, plywood, factories and straw board factories, sugar mills, packing case industries and furniture making. The timber comes from the forest of foothills of Shiwalik ranges.

\section{Degradation of Forest Resource}

There are mainly two factors causing degradation of forest cover in the watershed i.e. -natural factors and biotic factors

\section{(a) Natural Factor}

1. Frost- Frost is quite severe in the area and causes some damage to sal regeneration in the exposed areas. In bad years, it causes serious damage to sal saplings and poles by killing off their leading shoots and causing branchlessness and a bushy from at the top. The intensity of frost is more severe in low-lying areas, where there is no crop. Most of the frost occurs in December to late January, which is more severe and causes a lot of damage to sal crop.

2. Drought- Drought conditions affect the young forest plantations and the establishment of natural Sal regeneration. Although the area receives good rainfall, but most of it occurs during the monsoon, prior to which the hot summer takes its toll. Drought conditions persist also in the months of October to November.

3. Storms- Except in summer, winds is not particularly severe in this area. However, when strong winds follow heavy and continuous rainfall, some trees are uprooted while in others branches break and leaning of some trees also occurs. The dominant trees are sometimes affected by lightening, which splits the tree and kills it.

4. Floods and Erosion- Every year some damage is done to the forest during the monsoons, when the seasonal torrents extend their beds or change their course causing uprooting of the trees by eroding the soil. The flooding of the low-laying areas, which are not well drained, retards the progress of young plants. The erosion is further accelerated due to fires and grazing.

5. Plants- Evergreen weeds like lantana have invaded the forest area spreading quickly in any opening, forming almost impenetrable thickets. It is harmful for the natural regeneration of the forest species mainly sal. The climbers are generally heavy in the watershed area, Maljhan and Gauj, the two most common climbers, causes malformation of young trees and reduce the timber quality.

\section{(b) Biotic Factor}

1. Man- Man is the greatest enemy of the forest. Apart from the intentional forest cutting- and thefts of the forest products by the people, severe damage to the forest is caused by lopping of valuable species like sain, sandan, chal, padfal, khair etc. This practice causes injury to the trees, inviting insects and fungus. It also leads to slow extinction of the species, as there is no natural regeneration. Encroachment of the forest areas by influential patronized villagers, coupled with short-sighted gains of forest staff and their lack of security apart from the construction of forest roads and transfer of land to other department for various development works, also lead to the shrink in forest area.

Increasing population growth in the watershed area has put enormous pressure on forestland. People cut the vegetation from forest areas and convert them in agricultural land (Plate- $1 \mathrm{~A} \& \mathrm{~B}$ ). 


\section{PLATE- 1 A}
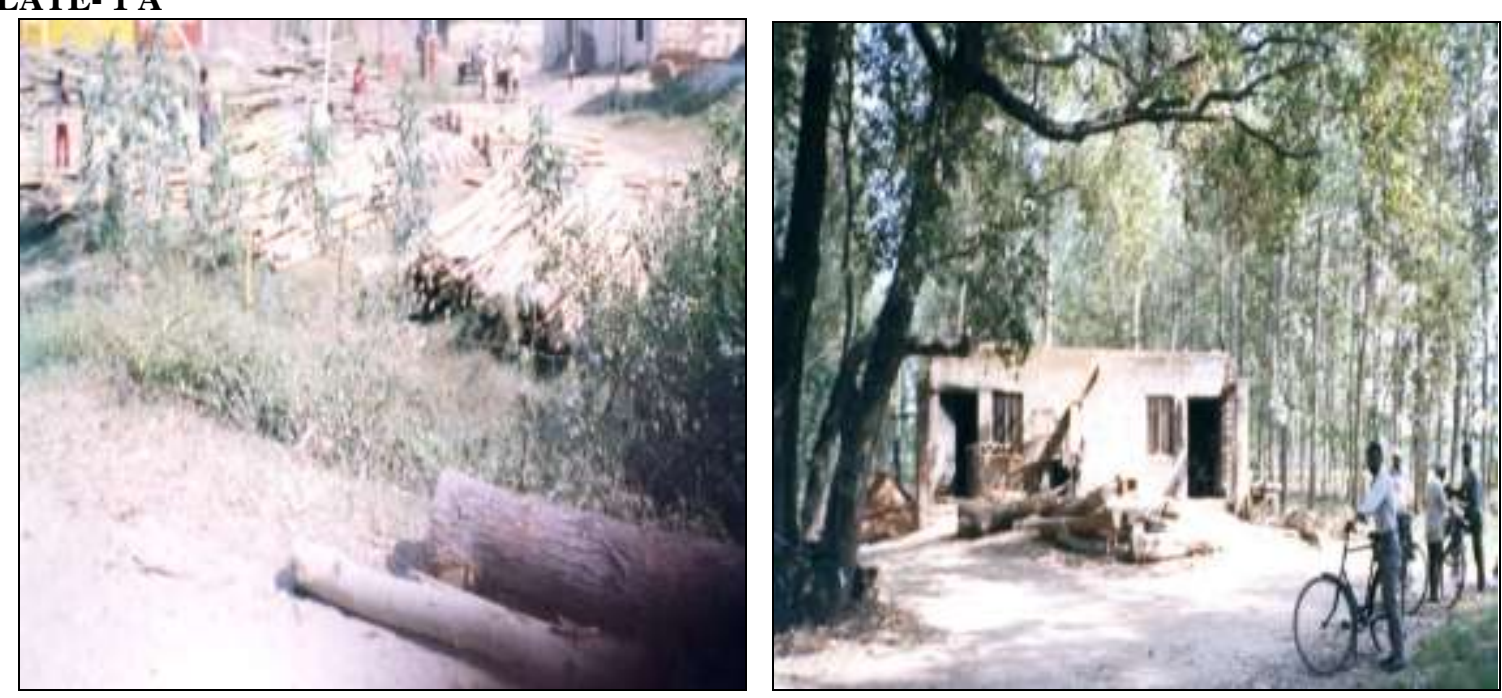

Cutting and extraction of wood from forest in watershed area

2. Animals- Both domestic animals as well as wild damage the forest vegetations through grazing. Grazing by domestic animals is extremely heavy all over the watershed area and the pressure is increasing from year to year resulting in soil erosion. The grazing limit far exceeds the carrying capacity of the forest. Wild animal like Nilgai, Pigs, Porcupines, Sambhar, Chital, Kakar and other animals cause some damage to young plantations. It is nowhere severe in the watershed. In arable area, they also damage the crops. Insects also damage the vegetation of forest to some extent. Many trees in the watershed have been infected with fungal attack, which has resulted in poor hygiene of the forest.

3. Fires- Fires in the watershed generally break out during the period of March to the advent of the monsoons. The summer being exceptionally hot and dry adds to the misery. Most of the fire in the watershed results due to the mischief of the local villagers, who set fire for getting good grass covers for grazing after rain.

\section{Conservation of Forest Resources}

Renewable natural resources, especially forests, are conserved for three major sets of purposes:

$>$ The maintenance of ecological processes and life support system

$>$ The sustained use of the resources for consumptive and social benefits

$>$ The conservation of biodiversity units own right for ethical, moral, aesthetic evolutionary resource.

Following methods should be carried out to conserve the vegetation cover in the watershed area-

a. Forest cutting is a big problem in the watershed. Degraded forest slopes mainly in the hilly areas accelerate the process of soil erosion. So afforestation programmes should be initiated to stop further soil erosion in the watershed.

b. The hills and foothills of the watershed face serve erosion hazards and inadequate vegetative cover. These areas must be closed during the rainy season and at the time of plantation to grazing and lopping so that natural vegetation cover gets change to establish. However, grass cutting after rainy season should be permitted as a preventive measure against fire hazards and to satisfy the full-fill the demands of the people. There should be complete prohibition on upslope encroachments into forest for cultivation, horticulture, grazing etc.

c. Sowing and planting of suitable species should be carried out intensively in a scientific manner for providing vegetative cover in the areas.

d. Forest conservation committee should be establish at the village level which involve the local people of that area and efforts should be done to educate the villagers about the importance of vegetation, soil and water of our present and future.

e. Several eroded land where top soil completely removed, existing as land without scrub, may be recommended in the isolated pediments for plantation of Eucalyptus.

f. In gullied areas check damming, gully plugging and other soil conservation works should be carried out to protect the area from erosion hazards.

g. Unstable slopes and landslips should be stabilized by planting plants.

h. In torrents Cho-training works should be done.

i. Staggered contour trenches should be dug out in areas for sediment control and to reduce run off and peak discharge. 
j. On slopes fodder tree (like Chhal, Khirak etc), Economic specially tree (like Khair etc.), Fodder grass (like Dhaulu etc.), and industrial grass (like Bhabbar) must be planted and effective vegetation cover should be provided on the slopes.

k. Those areas, which are in, close vicinity of the village. These areas have to be developed in such a way that the hills remain covered with grasses and trees to induce adequate water for supplemental irrigation to the poor farmers. Side by side, intensive planting of Bhabbar grass should be developed to provide raw material for rope making to the poor people. This should be protecting the hilly area.

\section{Reference}

[1] Allen, S.W. and Leonard J.W. (1966): Conserving Natural Resources, ( ${ }^{\text {rd }}$ ed.), Mc Grow Hill Book Co. New Yark.

[2] Anjaneyulu, Y (2004). Introduction to Environmental Science. BS Publications, Hyderabad.

[3] Gabler, Robert E, Petersen, James F, Trapasso, L. Michael and Sack Dorothy (2009): Physical Geography (9 ${ }^{\text {th }}$ Ed). Brooks/Cole Cengage Learning, USA

[4] Gole, P. (2001): Nature Conservation and Sustainable Development in India, Rawat Publication, Jaipur \& New Delhi.

[5] Goswami K.P. (2005): 'Forest as Resource and Component of the Environment, Its Degradation and Conservation: The Case Study of Gaya District', National Geographical Journal of India. Vol.-51, Pt. 1-2, pp. 81-92.

[6] Goudie A. (2001): The Nature of the Environment $\left(4^{\text {th }} \mathrm{ed}\right.$.). Blackwell Publishing Ltd., Oxford, U.K.

[7] Kajoba, Gear M. (2003): 'Land and Natural Resources Tenure Reform in Developing Countries: Lessons for Zambia' In Jha, V.C (ed.), Land Degradation and Desertification, Rawat Publication, Jaipur.

[8] Minakshi, Chaurasia, R., Sharma, P.K. (1999): 'Landuse/ Landcover Mapping and Change Detection Using Satellite Data- A Case Study of Dehlon Block, District Ludhiana, Punjab', Journal of the Indian Society of Remote Sensing, Vol. 27, No. 2, pp.151- 121

[9] Reddy, M Anji (2004): Geoinformatics for Environmental Management. BS Publication, Hydrabad, A.P.

[10] Tideman E.M. (2003): Watershed Management-guidelines for Indian Conditions. Omega Scientific Publishers, New Delhi. 